\title{
BMJ Open Description of the epidemiological characteristics of work-related eye injuries in Spain: a retrospective study
}

Sergio Martin-Prieto (iD , ${ }^{1}$ Cristina Álvarez-Peregrina, ${ }^{1}$ Israel Thuissard-Vasallo, ${ }^{1}$ Carlos Catalina-Romero, ${ }^{2}$ Eva Calvo-Bonacho, ${ }^{2}$ César Villa-Collar, ${ }^{1}$ Miguel Ángel Sánchez-Tena ${ }^{1}$

To cite: Martin-Prieto S, Álvarez-Peregrina C, ThuissardVasallo I, et al. Description of the epidemiological characteristics of workrelated eye injuries in Spain: a retrospective study. BMJ Open 2020;10:e035696. doi:10.1136/ bmjopen-2019-035696

- Prepublication history for this paper is available online. To view these files, please visit the journal online (http://dx.doi. org/10.1136/bmjopen-2019035696).

Received 12 November 2019 Revised 11 July 2020 Accepted 05 August 2020
Check for updates

(c) Author(s) (or their employer(s)) 2020. Re-use permitted under CC BY-NC. No commercial re-use. See rights and permissions. Published by BMJ.

${ }^{1}$ Biomedical and Health Science School, Universidad Europea de Madrid Campus de Villaviciosa de Odón, Madrid, Spain ${ }^{2}$ Health Project Department, Ibermutua (Mutua de accidentes de trabajo y enfermedades profesionales $n^{0} 274$ ), Madrid, Spain

Correspondence to Sergio Martin-Prieto martin.prieto.sergio@gmail.com

\section{ABSTRACT}

Objective To describe the epidemiological characteristics and trends of work-related eye injuries (WREls) in Spain over a 10-year period by sex, age and occupational sector. Design and settings A descriptive, retrospective and longitudinal study based on data from workers insured by a labour insurance company in Spain from 2008 to 2018 was presented. The study considered the ratio of the number of WREI per 100000 population and the relative risk of suffering an ocular injury. WREls were characterised by sex, age and occupational sector of injured workers.

Primary and secondary outcome measures Ratio of the number of WREI.

Participants In Spain, all workers are insured by a labour insurance company that provides cover in the event of work-related accidents. In this study, we have included all workers insured by one of these insurance companies, IBERMUTUA, with workers in all areas of Spain.

Results The study included 50265 WREl in the company over the 10-year period. Most of the injuries occurred in males (44 445; 88.4\%), in 35-44 age group (15 992; $31.8 \%$ ) and in industry workers (18 899; $42.6 \%)$. The average incidence was 429.75 per 100000 workers insured and 4273.36 per 100000 IBERMUTUA accidents (related and not related to eyes). Males, 16-24 age group and industry occupational sector group, have the highest incidence for WREI. The incidence of WREI decrease over the study period in all variables. Males have 6.56 (95\% Cl 6.38 to 6.75) times more risk of suffering WREI than females. 16-24 age group have 1.77 (95\% $\mathrm{Cl} 1.71$ to 1.83) times more risk than in the group of workers older than 55. Finally, industry workers have 7.73 (95\% Cl 7.55 to 7.92) times more risk than services workers.

Conclusions The risks of suffering WREl is higher for males, younger and less experienced workers, and for those who works in a manual task.

\section{INTRODUCTION}

An accident at work is defined in European Statistics on Accidents at Work methodology as a discrete occurrence during the course of work which leads to physical or mental harm. ${ }^{1}$ According to the Labour Force Survey, 6.9 million accidents at work occurred in the European Union in 2007, affecting $3.2 \%$ of the population. ${ }^{2}$ In 2017 , a total of

\section{Strengths and limitations of this study}

Data are collected from Ibermutua, one of the largest mutual insurance companies in Spain.

- This study has the highest number of workers in a research across Europe.

- This study covers a 10-year period, including an economic crisis during the period studied.

- Data are collected from only one mutual insurance company.

- Economic activities have been classified according to 2009 National Economic Activities Code and not divided into specific groups.

1.33 million of these accidents occurred in Spain, affecting $2.86 \%$ of the population. ${ }^{3}$ Within these statistics, work-related eye injuries (WREI) caused 16245 workers to be absent from work in 2017 and the eye was the most affected structure in the head.

The prevalence of ocular injuries in developed countries ranges from 88 to 1920 out of a 100000 population, ${ }^{45}$ depending on the origin and the type of ocular injury. León Hernández et at $\hat{l}^{\hat{b}}$ found that $20.2 \%$ of all ocular traumas in Spain in 1991 occurred in the workplace. The percentage of ocular injuries related to work changes along with the world from $0.84 \%$ to $3.4 \% .^{7-9}$ It depends on the type of population, the medical attention and the type of injury included in the study.

The universal plan of ocular health established by WHO for the period 2014-2019, has as a main goal decreasing vision impairment around the world. ${ }^{7}$ One of their secondary objectives is the generation of scientific data about the magnitude and causes of vision impairment in order to follow the progress and could define priorities. WREIs are one of these lesions related to vision impairment. Due to the characteristics of these injuries, they could be prevented by the creation of specific plans that just could be defined 
through the knowledge about the epidemiology and mechanism of WREI.

The main objective of this study was the epidemiological characterisation of WREI causing ocular injury in Spain by sex, age and occupational sectors over a 10-year period.

\section{METHODS}

A descriptive, retrospective and longitudinal study was performed. We analysed WREIs that affect any ocular structure during work time in a mutual insurance company. Study data were provided by IBERMUTUA, a mutual insurance company that collaborates with the Spanish Social Security system. Mutual insurance companies are non-profit private associations of business owners which are duly authorised by the Spanish Ministry of Employment and Social Security and registered with the Special Register operated by the said ministry. They aim to collaborate with the management of the Spanish Social Security system under its direction and auspices with members jointly assuming liability for the situations and with the scope established by the law. On these companies, medical specialists evaluate work accidents reported by the companies it insures, analysing the work-related injury and its consequences for insured workers. The study period was from 1 January 2008 to 31 December 2018.

The area of study covered all regions in Spain including Ceuta and Melilla with a population of 46650300 in $2018^{7}$ (latest census). In these years, we analysed 11696259 subjects (table 1), all of them IBERMUTUA-insured workers during the study period, and we related them to 201167800 workers in Spain. ${ }^{8}$

All medical records were anonymous; only statistical information was provided by Ibermutua for research purposes.

\section{Inclusion criteria}

We studied WREIs that affect any ocular structure during work time and in itinere. These injuries were evaluated and classified by medical specialists according to Clasificación Internacional de Enfermedades, 9th revisión, Modificación Clínica (CIE-9-MC) classification, correlations with Classification of diseases 10th version (ICD-10) that's is the new classification. According to WHO, ICD is the foundation for the identification of health trends and statistics globally, and the international standard for reporting diseases and health conditions. This allows making data comparisons in the same location across different periods. Ocular injuries are included in this classification with codes from 360 to 379 . Only injuries where any ocular structure was affected as the main injury were included in the study.

We analysed sex (males and females), age and occupational sector. We established five age groups (16-24, 25-34, 35-44, 45-54 and $\geq 55$ ) according to the Labour, Migrations and Social Security Ministry of Spain. ${ }^{3}$ The
Table 1 Total cases $(\mathrm{N})$ of Ibermutua-insured, Ibermutua accidents and total work-related eye injuries (WREI) according to sex, age and workers occupation

\begin{tabular}{|c|c|c|c|c|}
\hline & \multicolumn{2}{|l|}{ Total } & \multicolumn{2}{|c|}{ Losses } \\
\hline & $\mathbf{N}$ & $\%$ & $\mathbf{N}$ & $\%$ \\
\hline Ibermutua insured & 11696259 & & & \\
\hline Ibermutua accidents & 1179067 & & & \\
\hline Spanish workers & 201167800 & & & \\
\hline WREI & 50265 & & & \\
\hline \multicolumn{5}{|l|}{ Sex WREI } \\
\hline Male & 44445 & 89.3 & & \\
\hline Female & 5349 & 10.7 & & \\
\hline Total & 49794 & 100 & 471 & 0.9 \\
\hline \multicolumn{5}{|l|}{ Age group WREI } \\
\hline $16-24$ & 4388 & 8.8 & & \\
\hline $25-34$ & 14981 & 29.9 & & \\
\hline $35-44$ & 15992 & 32.0 & & \\
\hline $45-54$ & 10278 & 20.5 & & \\
\hline$>55$ & 4390 & 8.8 & & \\
\hline Total & 50029 & 100 & 236 & 0.5 \\
\hline \multicolumn{5}{|l|}{ Occupation WREI } \\
\hline Agriculture & 1624 & 3.7 & & \\
\hline Industry & 18899 & 42.6 & & \\
\hline Construction & 10455 & 23.6 & & \\
\hline Services & 13394 & 30.2 & & \\
\hline Total & 44369 & 100 & 5893 & 11.7 \\
\hline
\end{tabular}

Losses: total number of losses out of total number of cases (50 265) of WREI in all different groups.

occupational sector was classified according to the same Ministry's 2009 National Economic Activities Code (in Spanish), whereby occupational sector was divided into four groups: agricultural, industry, construction and services. ${ }^{3}$

\section{Statistical analysis}

Quantitative variables are given as a mean \pm SD. For qualitative variables, absolute and relative frequencies are given in percentages. To standardise data, the relationship between the number of WREI per 100000 population in Ibermutua (ratio/100 000 population) was calculated. Ibermutua data were divided into Ibermutua insured, which are the total number of workers insured by IBERMUTUA and IBERMUTUA accidents. Accidents refer to all the workers insured by Ibermutua that have suffered an accident in the 10 year period studied. A relative risk (RR) was computed to check the effects that exist between different groups of sex, age and occupational sector. To compare different groups in each variable, the lowest incidence per 100000 population on each group was considered as reference. RR shows how many times more of risk have a worker to suffer an accident respect the reference. 
A multiple logistic regression has been used to analyse the relationship between WREI and sex, age and occupation. The risk of suffering WREI was calculated from the OR obtained on this analysis taking as the reference the group with the lowest incidence.

The $\chi^{2}$ test and the Fisher's exact test were used to analyse qualitative variables. The student's t-test and the Mann-Whitney U-test were used, as appropriate, to search for significant differences between preferences.

The statistical analysis was performed using SPSS, V.21.0 (IBM), with $\mathrm{p}<0.05$ considered significant for all analyses.

\section{Patient and public involvement}

No patient involved.

\section{RESULTS}

There were 50265 WREI in Ibermutua over the 10-year period (table 1). These accidents affected $0.45 \%$ of all workers insured by IBERMUTUA and represented $4.22 \%$ of all accidents suffered by Ibermutua-insured workers (1 179067 total accidents (table 1$)$ ). The average age was $38.62 \pm 10.57$ and the majority of all injuries occurred in the 35-44 age group (15 992; 32.0\%). Within the subject population, 44445 were male $(89.3 \%)$ and 5349 females $(10.7 \%)$, and industry workers were the most affected group (18 899, 42.6\%) (table 1).

The incidence of WREI was 429.75/100 000 Ibermutuainsured workers and the incidence of WREI among Ibermutua-insured accidents was 4273.36/100 000.

Workers insured by Ibermutua constituted an average of $5.81 \%$ ( $\mathrm{SD} \pm 0.221$ ) of all workers in Spain, and the rate of change between workers insured in Ibermutua and total workers in Spain in the study period did not show statistically significant differences $(\mathrm{p}=0.9987)$ (figure 1$)$. This rate of change did not show statistically significant differences in services $(\mathrm{p}=0.070)$ and industry $(\mathrm{p}=0.453)$. The decrease in Spanish construction workers was statistical significance higher $(p=0.009)$ than Ibermutua construction insured over the study period, however, the

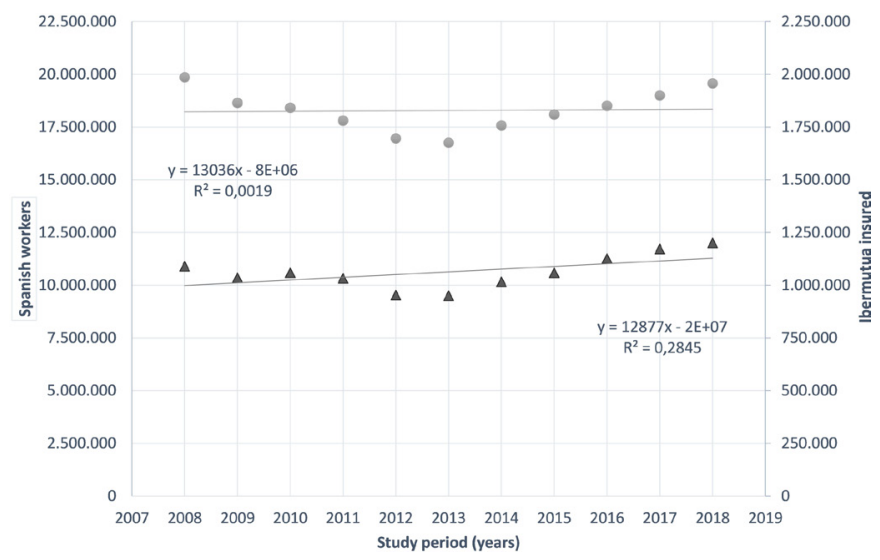

Figure 1 Relation between Ibermutua insured (triangle line) and Spanish workers (circle line) over the study period. There were no statistically significant differences in evolution over the 2008-2018 period ( $p=0.9987)$. trend is very similar. This trend was statistical significance different $(\mathrm{p}=0.02)$ in agriculture where Spanish workers decrease against Ibermutua insured who increased its number.

\section{Incidence and RR per $\mathbf{1 0 0} \mathbf{0 0 0}$ Ibermutua insured}

The incidence of WREI over the 10-year period was 680.12 per 100000 insured for males and 103.63 per 100000 insured for females. Therefore, males had $6.56(95 \%$ CI 6.38 to 6.75) times more RR of suffering WREI than females (table 2). If we analyse the evolution over the study period, a decrease in the incidence in both groups was observed. This decrease was statistically significant bigger in males than females ( $\mathrm{p}=0.00027$ ) (figure 2A).

The highest incidence by age group corresponds to the 16-24 group (561.16). The incidence decreases with age, 487.27 in $25-34,435.57$ in $35-44,369.42$ in $45-54$, and 316.69 in $\geq 55$ group (table 2 ). The $\geq 55$ age group is the reference for calculating the RR of suffering a WREI in the other groups because it is the group with the lowest incidence. In this case, RR decreases with age in the same way as the incidence (1.77 (95\% CI 1.71 to 1.83$), 1.54$ (95\% CI 1.51 to 1.57 ), 1.38 (95\% CI 1.35 to 1.41 ) and 1.17 (95\% CI 1.13 to 1.21)) (table 2). Over the study period, a decrease in the incidence of WREI in all age groups was observed, and it was statistically significant $(\mathrm{p}<0.05)$ when we compared 16-24 age group with the other groups, as well as when we compared 25-34 age group with 45-54 age group $(\mathrm{p}=0.035)$ and $25-34$ age group with $\geq 55$ age group ( $\mathrm{p}=0.021$ ) (figure $2 \mathrm{~B}$ ).

Industry workers were the occupation group with the highest incidence of WREI (1538.17), followed by construction workers (1381.52), agriculture workers (479.65) and, finally, services workers (198.92) (table 2). Therefore, in comparison with services workers, the risk of suffering an accident (RR) is 7.73 (95\% CI 7.55 to 7.92) times higher in Industry workers, 6.94 (95\% CI 6.77 to 7.12) times higher in construction workers, and 1.53 (95\% CI 1.45 to 1.61$)$ times higher in agriculture workers (table 2). A decrease in incidence was observed in all occupation groups over the period. There were statistically significant differences $(\mathrm{p}<0.05)$ when we compared all groups with each other, except for the two groups with the highest incidence, industry workers and construction workers $(\mathrm{p}=0.827)$ (figure $2 \mathrm{C})$.

\section{Incidence and RR per $\mathbf{1 0 0} \mathbf{0 0 0}$ Ibermutua accidents}

WREI incidence was 5125.26 for males and 1762.18 for females, with an RR 2.91 (95\% CI 2.83 to 299) higher in males (table 2). Incidence throughout the period decreases over time and is statistically significantly higher in males $(\mathrm{p}<0.001)$ than females (figure $3 \mathrm{~A})$.

In the same way as when we compared the incidence per 100000 Ibermutua insured, incidence and RR decrease with age. We observed the highest incidence and RR in 16-24 age group (5083.64 and RR 1.51 (95\% CI 1.46 to 1.56$)$ ), followed by $25-34$ age group (4800.23 and RR 1.43 (95\% CI 1.40 to 1.46)), 35-44 age group 
Table 2 Incidence of WREl over 100000 insured and 1000000 accidents and relative risk (RR) of work-related eye injuries (WREI) over a 10-year period according to sex, age and sector

\begin{tabular}{|c|c|c|c|c|c|c|c|}
\hline & \multirow{2}{*}{$\begin{array}{l}\text { WREI } \\
\text { incidence } \\
\text { per } 100000 \\
\text { accidents }\end{array}$} & \multirow[b]{2}{*}{$\begin{array}{l}\text { Risk percentage of } \\
\text { WREI (\%) }\end{array}$} & \multirow{2}{*}{$\begin{array}{l}\text { WREI } \\
\text { incidence } \\
\text { per } 100000 \\
\text { accidents }\end{array}$} & \multicolumn{2}{|c|}{$\begin{array}{l}\text { RR WREI according to } \\
\text { insured }\end{array}$} & \multicolumn{2}{|c|}{$\begin{array}{l}\text { RR WREI according to } \\
\text { accidents }\end{array}$} \\
\hline & & & & $\mathbf{R R}$ & $95 \% \mathrm{Cl}$ & RR & $95 \% \mathrm{Cl}$ \\
\hline Total & 425.73 & & 4253.29 & & & & \\
\hline Male & 680.13 & $\begin{array}{l}80.11 \%(95 \% \mathrm{Cl} 79.61 \% \\
\text { to } 80.61 \%)\end{array}$ & 5125.27 & 6.56 & 6.38 to 6.75 & 2.91 & 2.83 to 2.99 \\
\hline \multicolumn{8}{|l|}{ Age } \\
\hline Total & 427.74 & & 4273.36 & & & & \\
\hline $16-24$ years & 561.16 & $\begin{array}{l}64.15 \%(95 \% \mathrm{Cl} 63.11 \% \\
\text { to } 65.19 \%)\end{array}$ & 5083.65 & 1.77 & 1.71 to 1.83 & 1.51 & 1.46 to 1.56 \\
\hline $45-54$ years & 369.43 & $\begin{array}{l}55.45 \%(95 \% \text { Cl } 54.50 \% \\
\text { to } 56.39 \%)\end{array}$ & 3729.40 & 1.17 & 1.13 to 1.21 & 1.11 & $1, .07$ to 1.15 \\
\hline$>55$ Years & 316.69 & REF & 3368.01 & REF & & REF & \\
\hline \multicolumn{8}{|l|}{ Occupation } \\
\hline Total & 479.65 & & 4719.61 & & & & \\
\hline Agriculture & 305.14 & $\begin{array}{l}53.50 \%(95 \% \text { Cl } 52.33 \% \\
\text { to } 54.93 \%)\end{array}$ & 4495.75 & 1.53 & 1.45 to 1.61 & 1.72 & 1.64 to 1.81 \\
\hline Industry & 1538.18 & $\begin{array}{l}85.29 \%(95 \% \mathrm{Cl} 85.00 \% \\
\text { to } 85.57 \%)\end{array}$ & 8050.69 & 7.73 & 7.55 to 7.92 & 3.83 & 3.74 to 3.92 \\
\hline
\end{tabular}

(4364.93 and RR 1.30 (95\% CI 1.27 to 1.33 )), 45-54 years group (3729.39 and RR 1.11 (95\% CI 1.07 to 1.15 )), and, used as a reference and with the lowest incidence of all, the $\geq 55$ age group (3368.01). WREI incidence decreased in all age groups over time, and there was a statistically significant $(\mathrm{p}<0.05)$ decrease when we compared 16-24
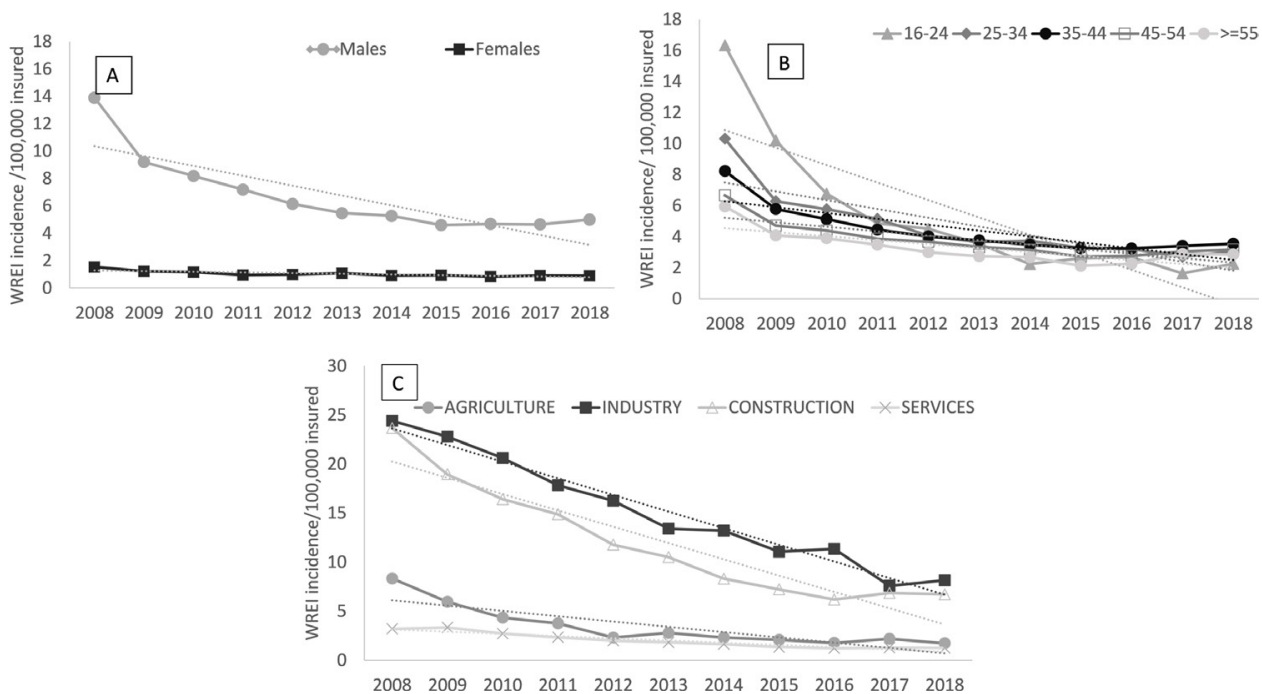

Figure 2 Evolution of WREl incidence per 100000 lbermutua insured over the study period. A decrease in incidence according to sex (A), age (B) and occupation (C) was observed. WREl, work-related eye injuries. 


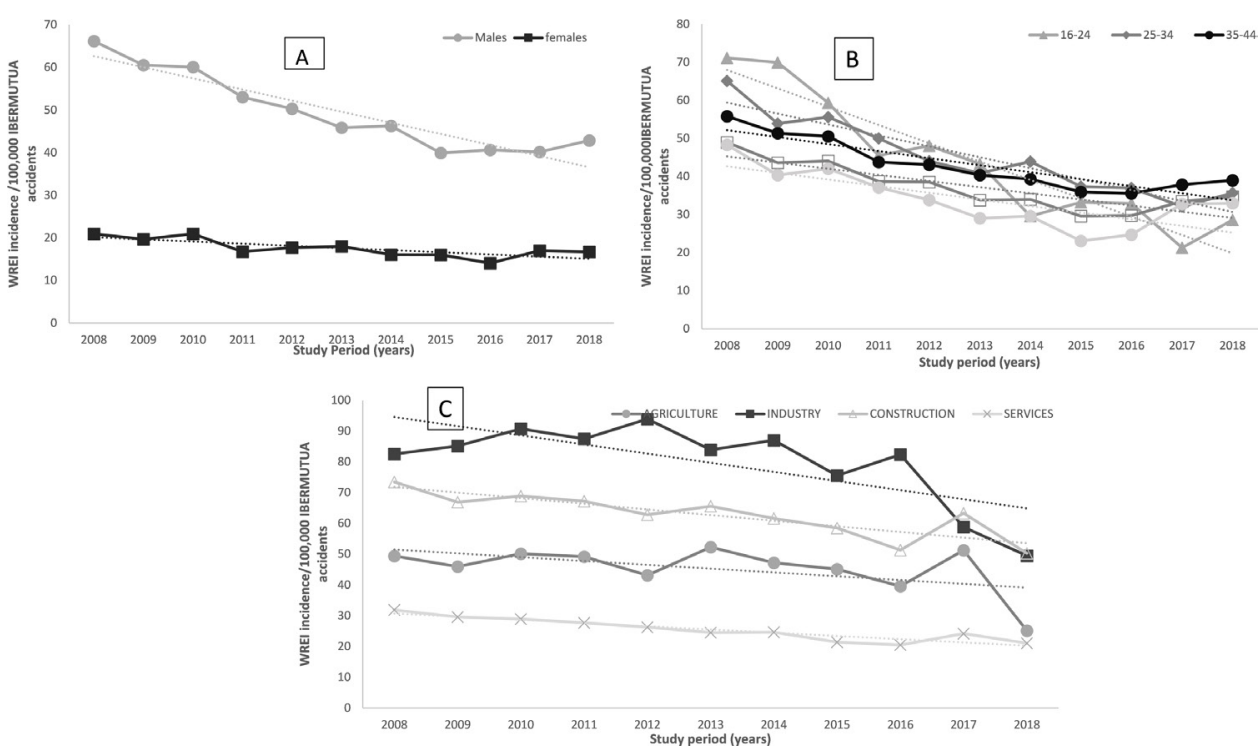

Figure 3 Evolution of WREI incidence per 100000 Ibermutua accidents over the study period. A decrease in incidence according to sex (A), age (B) and occupation (C) was observed. WREl, work-related eye injuries.

and 25-34 age groups with each other and both groups with the other groups (figure 3B).

Industry workers suffer the highest incidence and RR of WREI in the four occupation groups (8050.69; RR 3.83 (95\% CI 3.74 to 3.92)), followed by construction workers (6650; RR 2.54 (95\% CI 2.48 to 5.60)), agriculture workers (4495.75; RR 1.72 (95\% CI 1.64 to 1.81$)$ ), and, with the lowest incidence and RR of all, services workers (2615.64), the latter therefore being reference group for RR. Although we observed a decrease in incidence over the period, it was not statistically significant when we compared different groups (figure 3C).

Table 3 Relationship between WREl and study variables according to multivariate logistic regression analysis

\begin{tabular}{lll}
\hline & OR $(\mathbf{9 5} \% \mathbf{C l})$ & P value \\
\hline Sex & & \\
\hline Male & $4030(3904$ to 4159$)$ & $<0001$ \\
\hline Female & REF & REF \\
\hline Age (years $)$ & & \\
16-24 years & $1790(1711$ to 1873$)$ & $<0001$ \\
\hline 25-34 years & $1551(1496$ to 1608$)$ & $<0001$ \\
35-44 years & $1395(1346$ to 1446$)$ & $<0001$ \\
45-54 years & $1245(1198$ to 1293$)$ & $<0001$ \\
\hline 55 Years & REF & REF \\
\hline Occupation & & \\
\hline Agriculture & $1151(1098$ to 1219$)$ & $<0001$ \\
Industry & $4222(4111$ to 4336$)$ & $<0001$ \\
\hline Construction & $5799(5668$ to 5933$)$ & $<0001$ \\
\hline Services & REF & REF \\
\hline
\end{tabular}

WREI, work-related eye injuries.

\section{Interaction analysis between sex, age and occupation}

Table 3 shows how according to the the results of the multiple logistic regression analysis, there was significant relationship between WREI and sex, age and occupation. Males had $80.11 \%$ (95\% CI $79.61 \%$ to $80.61 \%$ ) more risk of suffering WREI than females. In addition, 16-24 age group showed the highest risk of suffering WREI compared with the lowest group (>55 years) $(64.15 \%$ (95\% CI $63.11 \%$ to $65.19 \%)$ ) and followed by the $25-34$ age group $(60.79 \%$ (95\% CI59.93\% to $61.65 \%)$ ), the $35-44$ age group (58.24\% (95\% CI $57.37 \%$ to $59.11 \%$ ) and the $45-54$ age group $(55.45 \%$ (95\% CI $54.50 \%$ to $56.39 \%)$ ).

Workers from the industry group had the highest risk of suffering WREI compared with those from the services group $(85.29 \%$ (95\% CI $85.00 \%$ to $85.57 \%)$ ). They were followed by workers from the construction $(80.85 \%(95 \%$ CI $80.43 \%$ to $81.26 \%)$ ) and agriculture sectors $(53.50 \%$ (95\% CI $52.33 \%$ to $54.93 \%)$ ).

\section{DISCUSSION}

Of all the long-term studies, we have observed in Europe, this is the one which covers the largest area and the highest number of cases. The close relationship between Ibermutua-insured workers and the evolution in the number of workers in Spain $(\mathrm{p}=0.9987)$ indicates the importance of our data analysis. The highest WREI incidence per 100000 Ibermutua insured/accidents and the highest RR was observed in males, aged between 16 and 24 that worked in the industry sector. The evolution of WREI incidence per 100000 insured/accidents over the study period showed a decrease in all the groups (both sexes and all ages and sectors).

The percentage of WREI in our study was lower than Gómez Villa et a ${ }^{\ominus}$ observed in two villages on the island 
of Mallorca (Spain) $(0.84 \%)$ Torino (Italy) $(1.3 \%)^{10}$ and much lower than another with a similar number of study cases in the USA $(3.4 \%) .{ }^{11}$ The difference was maybe due to the smaller area and population (only two villages and 50851 workers) and the shorter study period (2years) in Mallorca and the population in the USA and Torino is not only insured workers.

The total incidence of WREI falls between the values of other studies ${ }^{45}$ and is very similar to that found by Karlson and Klein ${ }^{12}$ in Wisconsin (USA) in 1986 $(423 / 100000)$. However, in all of these studies, the incidence does not relate exclusively to work-related injuries. If we compare only with WREI, in our study we observe higher incidence than in Hong Kong (around $125 / 100000) .{ }^{13}$ However, it is very difficult to compare these two values because the Hong Kong study covered a period of only 3 months.

The higher impact on males is similar to other studies where the percentage of eye injuries in males was between $87 \%$ and $95.1 \% .^{514-16}$ A very similar RR was observed in Modena (Italy) (7:1 male/female ratio), ${ }^{5}$ although it was lower in Taiwan (3.99) ${ }^{14}$ It is important to highlight that these studies included not only the active population, so results are eye injuries but not only related to work. This higher impact on males might be due to the different occupations in each group too. In the last quarter of 2018 in Spain, there were 2.8 times more men than women working in industry and 10.6 times more in construction. These are the two workers' occupational sectors where the highest WREI incidence was observed in our study. However, there were 1.054 million more female workers in services. ${ }^{17}$

Age group of 35-44 was the most affected age group in our study. Our data match those found in an area in the southwest of China. ${ }^{16}$ The highest percentage observed in other studies was in the 25-34 age group in Western Turkey ${ }^{15}$ and the 16-24 age group in Modena (Italy) ${ }^{5}$ However, we observed more incidence of WREI for 100000 insured in the lowest age group (16-24) in our study, and this incidence decreases with age. We only analysed workers population, and we think this is why we found more eye injuries in the lowest age group. These workers have less experience and perform more manual jobs too. Our results suggest that work experience plays a protective role in Spanish workers as well as in other countries. ${ }^{5} 1518$

As in other studies, ${ }^{5}$ we observed the highest incidence and percentage of WREI in industry workers. Agriculture was the most affected group in other studies ${ }^{19} 20$ but in all of them, services was the least affected group. This is due to the lower risk of trauma or other external agents that can affect services workers.

The multiple logistic regression analysis to study the interaction of the different variables, confirmed the results from the descriptive analysis. So, the highest incidence was observed in younger workers (aged between 16 and 24) and in males, confirming results from previous studies. $^{21}$
When we analysed the evolution of WREI for 100000 Ibermutua insured/accidents, we standardised data and eliminated WREI due to population variation. Therefore, we need to find reasons for the reduction in WREI in all study variables. This generalised decrease might be the result of unknown specific eye protection plans proposed by the companies and Ibermutua. Variation in occupational sector incidence over the study period could be another reason for this decrease. So, sectors with lower risk (agriculture and services) have increased his proportion $(81 \%$ in 2018 vs $73 \%$ in 2008$)$ and this makes that incidence of WREI also decrease in general.

There are no studies that compare WREI for accidents only (as opposed to total population). We considered it worth making this comparison to find out the mechanism and the importance that WREI have in total accidents in Spain. Using these data could make it easier to devise specific programmes aimed at reducing ocular accidents and the associated costs.

The high number of data of our database makes that a certain number of cases in the different variables was missing. Because of that, we don't have the same number of cases in all variables. These missed cases were not relevant in the sex and age group but were important in occupational sector groups (table 1). This becomes a limitation of our study and should be taken into account in future research in this area. Another limitation was the difficulty to compare with other studies where eye injuries are not only related to work, as far as they are carried out in the hospital's emergency departments.

\section{CONCLUSIONS}

There is a higher risk of WREI for workers from industry and construction when compare to agriculture and services. Our results suggesting that experience is also an important factor for WREI, because younger workers shown more risk of suffering WREI. With these results, the main risk factors for suffering WREI was to be male, to be young and less experienced and work in manual task.

According to these results, specific protection programmes for higher protection in industry and services sectors should be proposed. We suggest the implantation of protective glasses and face shields in industry workers and visual ergonomic measures or instilling eye-drops in workers of the services sector.

Contributors CAP, CVC and MAST designed the study. CCR and ECB obtained the data.The obtained data was analysed by SMP and IT-V. All authors contributed to the writing of the manuscript.

Funding The authors have not declared a specific grant for this research from any funding agency in the public, commercial or not-for-profit sectors.

Competing interests None declared.

Patient consent for publication Not required.

Ethics approval The research described herein adhered to the tenets of the Declaration of Helsinki and approved by the ethic investigation committee of Universidad Europea de Madrid (CEI-UE).

Provenance and peer review Not commissioned; externally peer reviewed. 
Data availability statement Data are available on reasonable request. All data relevant to the study are included in the article, however, these data are avalaible on a reasonable request. For this request, you can contact with the coresponding author on mail direction:martin.prieto.sergio@gmail.com.

Open access This is an open access article distributed in accordance with the Creative Commons Attribution Non Commercial (CC BY-NC 4.0) license, which permits others to distribute, remix, adapt, build upon this work non-commercially, and license their derivative works on different terms, provided the original work is properly cited, appropriate credit is given, any changes made indicated, and the use is non-commercial. See: http://creativecommons.org/licenses/by-nc/4.0/.

\section{ORCID iD}

Sergio Martin-Prieto http://orcid.org/0000-0002-9802-6238

\section{REFERENCES}

1 Eurostat. Statistics Explained - Accidents at work statistics. Eurostat Statistics Explained, 2015. Available: http://ec.europa.eu/eurostat/ statistics-explained/ [Accessed 1 Oct 2019].

2 Eurostat. Health and safety at work in Europe (1999-2007) - A statistical portrait. Publications Office of the European Union, 2010. Available: http://ec.europa.eu/eurostat/documents/3217494/ 5718905/KS-31-09-290-EN.PDF/88eef9f7-c229-40de-b1cd$43126 \mathrm{bc} 4 a 946$

3 Ministerio de empleo y seguridad Social. Dirección General de Estadística y Análisis Sociolaboral D. Resumen. Estadística de Accidentes de Trabajo 2017, 2017. Available: http://www.mitramiss. gob.es/estadisticas/eat/eat17/ATR_2017_Completa.pdf [Accessed 1 Oct 2019].

4 Sahraravand A, Haavisto A-K, Holopainen JM, et al. Ocular traumas in working age adults in Finland - Helsinki Ocular Trauma Study. Acta Ophthalmol 2017;95:288-94.

5 Gobba F, Dall'Olio E, Modenese A, et al. Work-Related eye injuries: a relevant health problem. main epidemiological data from a highlyindustrialized area of northern Italy. Int $J$ Environ Res Public Health $2017 ; 14: 604$.

6 León Hernández FA, Taboada Esteve JF, Guimerá V, et al. Primer año del estudio multicéntrico español sobre traumatismos oculares. Archivos de la Sociedad Epañola de Oftalmología 1991:p. 79-88.

7 Instituto Nacional de estadística (INE), Publicaciones oficiales BOE. España en cifras 2019, 2019. Available: http://www.ine.es/prodyser/ espa_cifras/2019/2/index.html
8 Instituto Nacional de estadística (INE). Sección prensa / Encuesta de Población Activa (EPA). Serie histórica (Datos en miles de personas), 2014. Available: https://www.ine.es/prensa/epa_tabla.htm [Accessed 18 Dec 2019].

9 Gómez Villa P, Ladaria Lliteras A. Patología oftálmica en el medio laboral: ergooftalmología, 2007. Available: http://diposit.ub.edu/ dspace/bitstream/2445/7101/1/PATOLOGIA OFTALMICA.pdf [Accessed 28 Dec 2019].

10 Fea A, Bosone A, Rolle T, et al. Eye injuries in an Italian urban population: report of 10,620 cases admitted to an eye emergency department in Torino. Graefes Arch Clin Exp Ophthalmol 2008;246:175-9.

11 Stagg BC, Shah MM, Talwar N, et al. Factors affecting visits to the emergency department for urgent and Nonurgent ocular conditions. Ophthalmology 2017;124:720-9.

12 Karlson TA, Klein BE. The incidence of acute hospital-treated eye injuries. Arch Ophthalmol 1986;104:1473-6.

$13 \mathrm{Yu}$ TSI, Liu H, Hui K. A case-control study of eye injuries in the workplace in Hong Kong. Ophthalmology 2004;111:70-4.

14 Ho C-K, Yen Y-L, Chang C-H, et al. Epidemiologic study on workrelated eye injuries in Kaohsiung, Taiwan. Kaohsiung J Med Sci 2007;23:463-9.

15 Serinken M, Turkcuer I, Cetin EN, et al. Causes and characteristics of work-related eye injuries in Western turkey. Indian J Ophthalmol 2013;61:497-501.

16 Cai M, Zhang J. Epidemiological characteristics of work-related ocular trauma in Southwest region of China. Int J Environ Res Public Health 2015;12:9864-75.

17 Instituto Nacional de estadística (INE). Encuesta de población Activa (EPA) 2018T4. Resultados Nacionales. Ocupados por grupo de edad, sexo y sector económico, 2018. Available: http://www.ine.es/jaxiT3/ Tabla.htm?t=3959 HYPERLINK "http://www.ine.es/jaxiT3/Tabla.htm? $\mathrm{t}=3959 \& \mathrm{~L}=0$ " \& HYPERLINK "http://www.ine.es/jaxiT3/Tabla.htm?t= 3959\&L=0" $\mathrm{L}=0$ [Accessed 8 Mar 2019].

18 Knyazer B, Bilenko N, Levy J, et al. Open globe eye injury characteristics and prognostic factors in southern Israel: a retrospective epidemiologic review of 10 years experience. Isr Med Assoc J 2013;15:158-62.

19 Jovanovic N, Peek-Asa C, Swanton A, et al. Prevalence and risk factors associated with work-related eye injuries in Bosnia and Herzegovina. Int J Occup Environ Health 2016;22:325-32.

20 Cruciani F, Lucchetta F, Regine F, et al. Work-Related accidents of ophthalmologic interest in Italy during 1986-1991. Ophthalmologica 1997;211:251-5.

21 Forrest KYZ, Cali JM. Epidemiology of lifetime work-related eye injuries in the U.S. population associated with one or more lost days of work. Ophthalmic Epidemiol 2009;16:156-62. 